\title{
COMPRESSIVE STRENGTH OF FOAMED CONCRETE IN RELATION TO POROSITY USING SEM IMAGES
}

\author{
P. Shawnim* and F. Mohammad* \\ School of Architecture, Design and the Built Environment, Nottingham Trent University, Burton Street, Nottingham, NG1 \\ 4BU, UK. \\ Date received: 12/10/2018, Date accepted: 26/03/2019 \\ *Corresponding author's email: paybar.shawnim2014@my.ntu.ac.uk and fouad.mohammad@ntu.ac.uk \\ https://doi.org/10.33736/jcest.1005.2019
}

\begin{abstract}
Foamed concrete (FC) specimens were examined for compressive strength at (28 and 180) days of air sealed curing, as well as at 28 days of water curing. The microstructure of 15 selected FC specimens was investigated for porosity in relation to compressive strength using Scanning Electron Microscopy (SEM) images. Twenty-two batches of FC specimens of the densities $\left(1100,1600\right.$, and 1800) $\mathrm{kg} / \mathrm{m}^{3}$ were made with fine sand and brick aggregates with toner and metakaolin (MK) inclusion as additives, they were casted in polystyrene cube moulds of (100x100x100) mm. The results showed that it is possible to produce FC with high compressive strength in the range of (28.5 to 59.2) N/mm², with a variety of materials, while the $1600 \mathrm{~kg} / \mathrm{m}^{3}$ density with the inclusion of toner and MK20 is the favourite, which can be used for structural elements. Conventionally, compressive strength is in an inverse relationship with porosity, as porosity increases, compressive strength decreases, but using toner and MK20 can alter this relationship between porosity and compressive strength, whereby it is possible to produce a relatively light weight high porosity FC matrix to exhibit high compressive strength. Maturity of the FC at 180 days demonstrated an increase in the compressive strength. The microstructural investigations through SEM images revealed that the FC mix made with sand or brick only exhibited an irregular shape factor of the micro pore system with the pore size in the range of (10 to 70) $\mu \mathrm{m}$, while those made with the inclusion of toner and MK20 had a regular shape factor of a matrix of finer micro pore system of the sizes in the range of ( 0.01 to 10.0$) \mu \mathrm{m}$, all of which were evenly distributed, and exerted massive influence on the properties of the FC, particularly, on compressive strength. On the contrary to the conventional method of air sealed curing for FC, the water curing method can equally give the same or slightly better result in respect of compressive strength for some particular densities.
\end{abstract}

Copyright (C) 2019 UNIMAS Publisher. This is an open access article distributed under the Creative Commons Attribution-NonCommercial-ShareAlike 4.0 International License which permits unrestricted use, distribution, and reproduction in any medium, provided the original work is properly cited.

Keywords: Compressive strength, foamed concrete, porosity, SEM, toner

\subsection{INTRODUCTION}

Foamed concrete (FC) is a lightweight material made of Ordinary Portland cement paste (OPC and a filler, usually sand) and water with well-spread air voids or pore structure created by the introduction of air by mechanical means of foaming. The foam can be originated from an agent made of natural surfactants or synthetic materials, and can be added to the concrete mix either as pre-foamed (where the foam is prepared in advance by the foaming machine and added later) or as mixed foaming (the foam is added to the mix at the same time as it is prepared) [1]. Foamed concrete is a lightweight material with low densities between $(400-1800) \mathrm{kg} / \mathrm{m}^{3}$ [2] incorporating a high volume of air, highly workable, selfflowing, self-compacting, and self-levelling with fire resisting, thermal insulating and sound proofing properties. The typical strength value for FC of densities between $(800-1600) \mathrm{kg} / \mathrm{m}^{3}$ ranged between $(1-10) \mathrm{N} / \mathrm{mm}^{2}$ [3]. Foamed concrete produced in this range can only be used for general purposes, such as gap fillings. At a minimum strength of $25 \mathrm{~N} / \mathrm{mm} 2, \mathrm{FC}$ has the potential to be used as a structural material [4], [5]. Table 1 presents the maximum compressive strength of $28.5 \mathrm{~N} / \mathrm{mm}^{2}$ for $1800 \mathrm{~kg} / \mathrm{m}^{3}$ density [6]. 
Table 1 Compressive strength of foamed concrete at different densities [6]

\begin{tabular}{ccc}
\hline Fine aggregate type & Plastic density $\left(\mathrm{kg} / \mathrm{m}^{3}\right)$ & 28-day compressive strength $\left(\mathrm{N} / \mathrm{mm}^{2}\right)$ \\
\hline \multirow{2}{*}{ Sand } & 1400 & 13.5 \\
& 1600 & 19.5 \\
\end{tabular}

Ramamurthy et al., [7] found that at lower density, the foam volume controlled the strength rather than the material properties, hence, the compressive strength is primarily a function of density. Visagie and Kearsley [8] found that at higher densities, the air void distribution did not influence the compressive strength, which may be related to a more uniform distribution of voids at higher densities. Luping [9] stated that bigger pores affected the strength of concrete rather than the smaller pores for materials with similar matrix and porosity, while the strength was lower for that containing more of the large size pores. Durack and Weiqing [10] showed that for products of comparable density, air-cured foam concrete made with cement-sand and cement-fly ash for masonry, mixes with fly ash as fine aggregate in place of sand, gave relatively higher strength.

\subsection{METAKAOLIN AS ADDITIVE IN CONCRETE}

Metakaolin (MK) is considered as ultrafine pozzolanic material, produced by calcining purified kaolinite clay at a temperature ranging from 700 to $900 \mathrm{C}^{0}$ [11] and [12]. MK utilization is considered as environmental-friendly, for that, it helps in the reduction of Portland cement consumption (PC), which in turn, refers to the reduction of $\mathrm{CO}_{2}$ emission into the surrounding. For the chemical composition of $\mathrm{MK}$ and PC, please refer to Table 2.

Table 2 Chemical composition of Portland Cement (PC) and Metakaolin (MK)

\begin{tabular}{|c|c|c|}
\hline Composition & OPC (\%) & $\operatorname{MK}(\%)$ \\
\hline $\mathrm{SiO}_{2}$ & 20.1 & 52 \\
\hline $\mathrm{Fe}_{2} \mathrm{O}_{3}$ & 2.3 & 4.6 \\
\hline $\mathrm{Al}_{2} \mathrm{O}_{3}$ & 4.4 & 41 \\
\hline $\mathrm{CaO}$ & 63.4 & 0.1 \\
\hline $\mathrm{MgO}$ & 2.3 & 0.2 \\
\hline $\mathrm{SO}_{3}$ & 3.2 & - \\
\hline $\mathrm{Na}_{2} \mathrm{O}$ & 0.14 & 0.1 \\
\hline $\mathrm{K}_{2} \mathrm{O}$ & 0.67 & 0.6 \\
\hline $\mathrm{TiO}_{2}$ & - & 0.81 \\
\hline LOI & 2.81 & 0.6 \\
\hline
\end{tabular}

Studies in this field have shown that inclusion of MK gave good influence on the physical and mechanical properties, as well as on durability of concrete [13] and [14]. Bai et al. [15] found that MK highly contributed to early strength development as an accelerating admixture for PC and PC-PFA concrete, whereas $\mathrm{MK}$ as an admixture in PC concrete displayed a major role on the compressive strength up to $30 \%$ greater than that of the plain concretes, depending mainly on replacement level of $\mathrm{MK}$, w/c ratio, and testing age, in particular at the early age of day one, where strength enhancement was noticed.

\subsection{CLAY BRICK AGGREGATES (COARSE AND FINE) AS ADDITIVE IN CONCRETE:}

Table 3 shows the Chemical composition of the cementitious materials of clay brick. Debieb and Kenai [16] used both coarse and finely ground clay bricks, and found that the strength decreased in the range of $20 \%$ to $30 \%$ depending on the degree of substitution. Also, using only ground bricks as fine aggregates, Khatib [17], and Poon and Chan [18] found a decrease in strength. 
Table 3 Chemical composition of the cementitious materials of clay brick

\begin{tabular}{cc}
\hline Composition & Ground clay brick powder $(\mathrm{GBP})(\%)$ \\
$\mathrm{CaO}$ & 0.81 \\
$\mathrm{SiO}_{2}$ & 69.9 \\
$\mathrm{Al}_{2} \mathrm{O}_{3}$ & 15.38 \\
$\mathrm{Fe}_{2} \mathrm{O}_{3}$ & 6.78 \\
$\mathrm{MgO}$ & 1.58 \\
$\mathrm{SO}_{3}$ & 0.04 \\
$\mathrm{~K}_{2} \mathrm{O}$ & 2.78 \\
$\mathrm{Na}_{2} \mathrm{O}$ & 1.02 \\
Loss on ignition & 0.16 \\
\hline
\end{tabular}

Cachim [19] found no effect on the strength when ground clay brick was used up to $15 \%$ substitute to natural aggregates, but a reduction of up to $20 \%$ at $30 \%$ substitute (depending on the type of brick). He added that the stress-strain relations are very similar for the concrete made with clay brick aggregate. Debieb and Kenai [16] reported a decrease in compressive strength of about 30, 35 and $40 \%$ at 28 days of age when coarse, fine, or both fine and coarse aggregates were substituted, in which they also found densities of ground clay brick concrete compared to those of natural aggregates were lower by (up to 17\%). As for modulus of elasticity, a reduction of 30\%, $40 \%$ and $50 \%$ was observed for concrete made with coarse, fine and both coarse and fine ground bricks. Therefore, Debieb and Kenai [16] and Ibrahim et al. [20] restricted the limit to $25 \%$ and $50 \%$ for the coarse and fine aggregates as an optimum percentage to produce a quality concrete with characteristics similar to those of natural aggregates concrete, as it provided better properties of lightweight concrete (compressive strength and durability), because they found at $25 \%$ substitution of clay brick showed the highest compressive strength of $25 \mathrm{MPa}$ with density of $1647 \mathrm{~kg} / \mathrm{m}^{3}$.

Aliabdo et al. [21] supported the above phenomena, stating that ground clay brick aggregates content should not exceed $25 \%$ of total aggregate content, as exceeding this limit content will result in porous and bad volume stability of FC. Besides, $25 \%$ and $50 \%$ replacement percentages of clay brick aggregate enhanced the splitting tensile strength of FC. They found that at 25\% clay brick aggregate, it had no significant effect on compressive strength, especially at prolonged curing, but on compressive strength enhancement at 50\% replacement of ground brick powder, which may be produced from its pozzolanic characteristics. Porosity increased as well, when increasing ground clay brick content, resulting in porous structure. Aliabdo et al. [21] recommended that clay brick powder to be saturated for FC mixes to enhance workability and volume stability. This is also supported by Cachim [19] and Ibrahim et al. [20] for clay brick saturation, and stated that incorporation of clay brick into the concrete will increase the workability.

\subsection{TONER}

This is a new material in the field of FC to be researched, therefore, no experimental data is available. This material is in the form of a black powder, which was used as an additive to the experimental mixes, at $1 \%$ and $5 \%$ of the binding cementitious material (OPC). This material was chosen for this research because it is widely available as a waste material for recycling and to generate a cleaner environment by reducing buried waste and $\mathrm{CO}_{2}$ emission around the world. Table 4 shows the chemical composition for toner, wherein toner includes the following additives for flow and lubrication purposes: Fumed silica and metal stearates. 
Table 4 Chemical composition of toner [22].

\begin{tabular}{cc}
\hline Toner Type & Composition \\
\hline Plastic (Styrene acrylate copolymer, polyester resin) & $65-85 \%$ or $55-65 \%$. \\
iron oxide & $6-12 \%$ or $30-40 \%$. \\
Wax, ground sand & $1-5 \%$ \\
Amorphous silica & $1-3 \%$ \\
Carbon black & $1-10 \%$. \\
\hline
\end{tabular}

\subsection{EXPERIMENTAL WORK}

This paper experimentally examined compressive strength at (28 and 180) days air sealed curing, as well as at 28 days of water cured for structural use at $28.5 \mathrm{~N} / \mathrm{mm}^{2}$ [6], and investigated the microstructure of the FC matrix to determine porosity in relation to compressive strength. The experiments were carried out in the laboratory in accordance to the relevant British Standards (BS) for each part of the process. Twenty-two batches of different concrete mixes were made with OPC, fine sand $(0-0.5) \mathrm{mm}$, and brick $(0-0.5$ and 10.0) $\mathrm{mm}$ as filler, while MK and toner were added at different doses as additives with a w/c ratio of 0.5 . Addition of toner at $1 \%$ or $5 \%$ by weight of the cement had no effect on water demands for the mixes involved. These batches were casted in $(100 \times 100 \times 100) \mathrm{mm}$ disposable polystyrene cube moulds, air sealed for the desired period of (28 and 180) days prior to testing, with only a number of selective densities of (1100 and 1600) $\mathrm{kg} / \mathrm{m}^{3}$ chosen for water curing at 28 days for comparison (see Figure 1). The foam was added at different percentages to the mixes to produce the desired densities, in which the results are expressed in $\left(\mathrm{kg} / \mathrm{m}^{3}\right)$ of the dried weight. The foaming agent used in this project was a protein-based foaming agent, whereby dry pre-foaming method was used to generate the foam. The cement content of the FC for all the batches was kept constant at $(500-600) \mathrm{kg} / \mathrm{m}^{3}$ which is compatible with other researches carried out in this field [22].

As for the microstructural investigation of the FC matrices, samples taken from 15 selective specimens were studied via secondary electron (SE) and backscattered electron (BS) images, which were captured using Scanning Electron Microscopy (SEM) in the form of 2D-images, in which the images were analysed using Image J software. Images were taken at 500X, $2000 \mathrm{X}$, and 10000X magnification, while the 2000X magnification was taken for analysis in this study for clarity to meet the purpose. For this technique, samples of about $10 \times 10 \mathrm{~mm}$ size with a thickness of about $6 \mathrm{~mm}$ were cut from the cured specimens using microtome (a diamond cutter). In order to produce the best electron images and to eliminate distortion of the SE and BSE images due to negative charges, the samples were coated and polished with slow set epoxy resin and with a thin film of gold (conductive material) before placing them into the SEM chamber, which is compatible to the techniques used in this field [24].

Porosity as a percentage ratio (\%), pore sizes and pore size distribution of the selected 15 specimens, namely (S3, S4, S5, S7, S8, S10, S11, S12, S13, S14, S15, S16, S18, S19 and S20), were found in the area under investigation (see Table 5). 
Table 5 Showing compressive strength in $\left(\mathrm{N} / \mathrm{mm}^{2}\right)$ for different curing methods and tests of the specimens, S1 to S22, with porosity ratio $(\%)$.

\begin{tabular}{|c|c|c|c|c|c|c|c|}
\hline Label & Type of concrete cast: & $\begin{array}{c}\text { Dry } \\
\text { Density } \\
\left(\mathrm{Kg} / \mathrm{m}^{3}\right)\end{array}$ & $\begin{array}{c}\text { Compressive } \\
\text { strength } 28 \\
\text { days sealed } \\
\left(\mathrm{N} / \mathrm{mm}^{2}\right)\end{array}$ & $\begin{array}{c}\text { Compressive } \\
\text { strength } 28 \\
\text { days water } \\
\text { cured } \\
\left(\mathrm{N} / \mathrm{mm}^{2}\right)\end{array}$ & $\begin{array}{c}\text { Compressive } \\
\text { strength } 180 \\
\text { days sealed } \\
\left(\mathrm{N} / \mathrm{mm}^{2}\right)\end{array}$ & $\begin{array}{l}\text { Porosity } \\
(\%)\end{array}$ & $\begin{array}{l}\text { Ratio of } 180 \\
\text { to } 28 \\
\text { compressive } \\
\text { strength } \\
(\%)\end{array}$ \\
\hline S1 & Sand & 2000 & 53.3 & & 58.5 & & 9.8 \\
\hline S2 & Sand & 1800 & 31 & & 33.1 & & 6.8 \\
\hline S3 & Sand & 1100 & 7.4 & 7.8 & 8.1 & 60 & 9.5 \\
\hline S4 & Sand and MK20 & 1800 & 49.7 & & 54.5 & 39.8 & 9.7 \\
\hline S5 & Sand and MK20 & 1600 & 47 & 49.1 & 58 & 54 & 23.4 \\
\hline S6 & Sand and MK20 & 1100 & 10.2 & 11.6 & 11.7 & & 14.7 \\
\hline S7 & Sand and MK30 & 1600 & 38 & 39.3 & 44.2 & 65.1 & 16.3 \\
\hline S8 & Sand and MK30 & 1100 & 31 & 32.2 & 33.7 & 70 & 8.7 \\
\hline S9 & Sand and MK50 & 1600 & 30 & 31.6 & 35.6 & & 18.7 \\
\hline S10 & Sand and MK50 & 1100 & 26.1 & 27.2 & 28.3 & 77.7 & 8.4 \\
\hline S11 & Brick aggregates & 1800 & 47.3 & & 51.7 & 46.4 & 9.3 \\
\hline $\mathrm{S} 12$ & Brick aggregates & 1600 & 40.6 & 42.1 & 47.4 & 53.5 & 16.7 \\
\hline $\mathrm{S} 13$ & Brick aggregates & 1100 & 14.1 & 15.2 & 18.3 & 66 & 29.8 \\
\hline S14 & Brick and MK20 & 1600 & 46 & 47.9 & 48.3 & 44.5 & 5.0 \\
\hline S15 & Brick and MK20 & 1100 & 25.6 & 27.4 & 30.6 & 51.6 & 19.5 \\
\hline S16 & Sand and Toner & 1800 & 48.1 & & 59 & 39.6 & 22.7 \\
\hline S17 & Sand and Toner (5\%) & 1800 & 55.1 & & 59.2 & & 7.4 \\
\hline S18 & Sand and Toner & 1100 & 15 & 16.2 & 17.9 & 57.7 & 19.3 \\
\hline S19 & Brick and Toner & 1600 & 43.8 & 45.1 & 48.2 & 46.6 & 10.0 \\
\hline $\mathrm{S} 20$ & Brick and Toner & 1100 & 33.4 & 34.5 & 36 & 57 & 7.8 \\
\hline $\mathrm{S} 21$ & Brick and Toner (5\%) & 1600 & 50.5 & 52.1 & 56.7 & & 12.3 \\
\hline S22 & Brick and Toner (5\%) & 1100 & 38.2 & 39.3 & 41 & & 7.3 \\
\hline
\end{tabular}

\subsection{COMPRESSIVE STRENGTH AT (28 AND 180) DAYS}

The test was carried out with digital log keeping and digitally controlled automatic loading machine in accordance with BS EN 12390-3:2009 [25]. The oven-dried cubes were placed centrally under the loading plates and positioned to have even surfaces in contact with the loading plates, (see Figures 2 and 3 ). The results quoted in each case are the average of six specimens. 


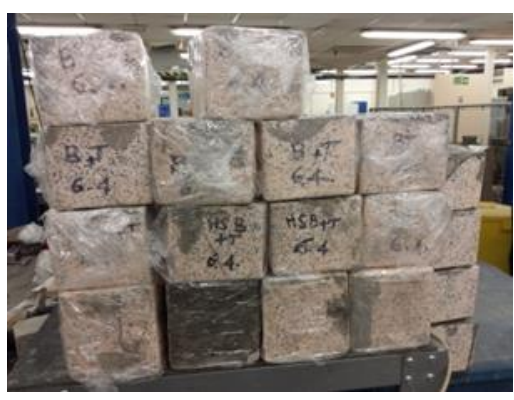

Figure 1 Sealed cubes in cling film for curing

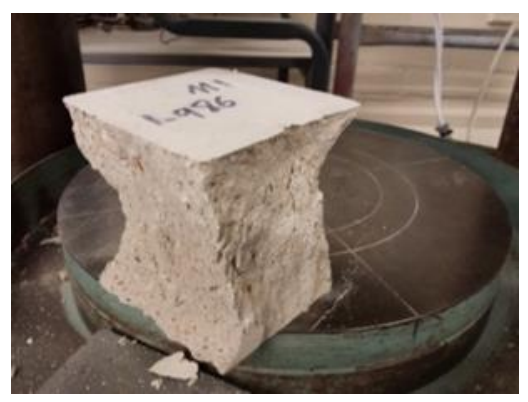

Figure 2 Cube between plates under compression

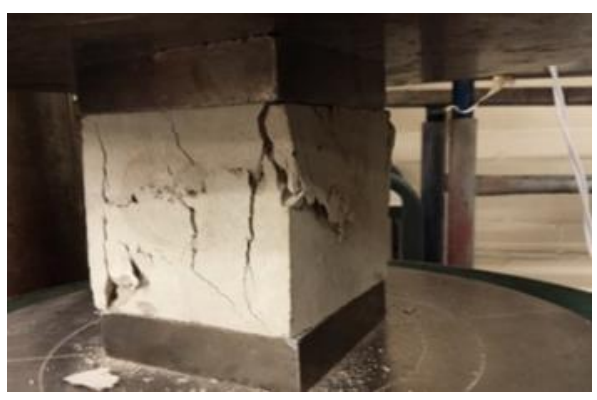

Figure 3 Cube after crushing

\subsection{RESULTS AND DISCUSSION}

For the compressive strength at (28) days of curing, Figure 4 illustrates that at $1600 \mathrm{~kg} / \mathrm{m}^{3} \mathrm{densities,} \mathrm{a}$ part of S9, which is too close for the same density, specimens S21, S5, S14, S19, S12, S7, S2 and S9 of $(50.5,47,46,43.8,40.6,38,31$ and 30) N/mm², either toner or MK20 inclusion of sand or brick, gave higher compressive strength than the $28.8 \mathrm{~N} / \mathrm{mm}^{2}$ (see Table 1) [6]. This means; high strength FC is possible to produce, using sand or brick as a filler with toner or MK20 inclusion, for which this is true even at low densities as $1100 \mathrm{~kg} / \mathrm{m}^{3}$, specimens S22, S20 and S8 of $(38.2,33.4$ and 31) N/mm².

In fact, compressive strength for S21 of $50.5 \mathrm{~N} / \mathrm{mm}^{2}$ of $5 \%$ toner inclusion, S5 of $47 \mathrm{~N} / \mathrm{mm}^{2}$ sand made with MK20 inclusion, S14 of $46 \mathrm{~N} / \mathrm{mm}^{2}$ brick made with MK20 inclusion, and S17 of $55.1 \mathrm{~N} / \mathrm{mm}^{2}$ with toner inclusion at $5 \%$, was higher than S1 (the controlled normal concrete) of $2000 \mathrm{~kg} / \mathrm{m}^{3}$ density, with $53.3 \mathrm{~N} / \mathrm{mm}^{2}$. This is followed by $\mathrm{S} 4, \mathrm{~S} 16$ and $\mathrm{S} 11$ of $(49.7,48.1$ and 47.3$) \mathrm{N} / \mathrm{mm}^{2}$, with a close range compressive strength. All the latter specimens of $1800 \mathrm{~kg} / \mathrm{m}^{3}$ density, plus $\mathrm{S} 2$ of $31 \mathrm{~N} / \mathrm{mm}^{2}$, showed higher compressive strength than that presented in Table 1.

The reaction between the constituents of toner (i.e. iron oxide, lubricating metal stearates, and silica with chemical composition of the binding material), gave a fine coating film around the binding particles and the air voids, producing water-resistant, strong, and compacted intercellular bond, which in turn, improved the properties in respect of higher compressive strength and less permeability. MK displayed pozzolanic reactivity with the binding materials, produced stronger FC matrix through interconnecting air voids (micro pores) and interlocking channels found to be in a fine range for toner, and MK inclusion of the size of ( 0.01 to 10$) \mu \mathrm{m}$ that gave finer less porous and less permeable matrix. As a result, poor water movement may percolate through these micro pores of the interlocking channels, while maintaining the strength with a firm skeleton.

Brick particles, on the other hand, are porous to a certain degree, which have the ability to absorb more water and keep it as a reserve for better curing later. The brick powder has pozzolanic reactivity, adding to the strength and pore refinement, improving size and number of pores as well as pore size distribution within the FC matrix when reacting with the MK20 and toner, i.e. minimising porosity, which in turn, improving strength increase.

In examining the 180-day specimens of the same density of $1600 \mathrm{~kg} / \mathrm{m}^{3}$, from Figure 4, specimens S5, and S21 of (58 and 56.7) N/mm ${ }^{2}$ showed higher compressive strength than $\mathrm{S} 1$ of $53.3 \mathrm{~N} / \mathrm{mm}^{2}$, followed by S14, S19, S12 and S7 of $\left(48.3,48.2,47.4\right.$ and 44.2) N/mm ${ }^{2}$, respectively, which are within a close range. All the rest of the specimens, from S2 to S22, a part of S3, S6, S13 and S18, showed higher compressive strength than $28.5 \mathrm{~N} / \mathrm{mm}^{2}$ of Table 1 , and only S10 of $28.3 \mathrm{~N} / \mathrm{mm}^{2}$ was almost the same. In fact, specimens S22, S20, S15, and S8 are of the low density of $1100 \mathrm{~kg} / \mathrm{m}^{3}$, here again, toner at $(1 \%$ and $5 \%$ ), MK20 and MK30 inclusion contributed to this. All water-cured specimens of 28 days' curing, which were selected at (1100 and 1600) $\mathrm{kg} / \mathrm{m}^{3}$ densities, namely S3, S5 to S10, S12 to S15 and S18 to S22, 
showed almost the same or just over the air sealed cured specimen compressive strength. This means; they are exactly subjected to the same analysis as for the 28 days of air-cured specimens mentioned above, and it can be said that contrary to what is conventionally followed, FC can be water-cured for the 28 days' duration to get the same or slightly better results for that of air curing. At $1800 \mathrm{~kg} / \mathrm{m}^{3}$ densities, specimens S17, S16, S4 and S11 with (5\% toner, $1 \%$ toner, MK20 and brick made) respectively, having (59.2, 59, 54.5 and 51.7) $\mathrm{N} / \mathrm{mm}^{2}$, showed higher (or a very close range of) compressive strength than the controlled normal concrete of $\mathrm{S} 1$ of $2000 \mathrm{~kg} / \mathrm{m}^{3}$ density with $53.3 \mathrm{~N} / \mathrm{mm}^{2}$.

Strength in relation to porosity through SEM images, looking at the $1100 \mathrm{~kg} / \mathrm{m}^{3}$ densities from Figures 5 and 6, specimens S8 and S10 with (70 and 77.7) \% porosity are of (31 and 26.1) N/mm ${ }^{2}$ compressive strength respectively, while S3 and S13 with lower $60 \%$ and $66 \%$ porosity, showed $(7.4$ and 14.1$) \mathrm{N} / \mathrm{mm}^{2}$. As the pore sizes and their distribution over the FC matrix were investigated, S3 and S13 displayed an un-evenly distributed bigger inter-connected pore sizes in the range of $>10 \mu \mathrm{m}$, i.e. (10 to 70) $\mu \mathrm{m}$ with irregular shapes. While S8 and S10 exhibited an evenly well-spread net of independent relatively finer size pores in the range of ( 0.01 to 10$) \mu \mathrm{m}, \mathrm{S} 4$ and $\mathrm{S} 16$ of $1800 \mathrm{~kg} / \mathrm{m}^{3}$ densities with almost the same $39.8 \%$ and $39.6 \%$ porosity, made with MK20 and toner inclusion, had (49.7 and 48.1) N/mm ${ }^{2}$ respectively, the pore sizes and their distribution were too close to each other, MK20 of (0.01 to 10.0) $\mu \mathrm{m}$ pore size, and toner of (0.01 to 3.0) $\mu \mathrm{m}$.

Toner and MK20 inclusion, in refining the pore matrix to make the specimens stronger, S14 and S19 of $1600 \mathrm{~kg} / \mathrm{m}^{3}$ densities with (44.5 and 46.6) \% porosity, displayed (46 and 43.8) N/mm² compressive strength, again, the pore size and their distribution analysis gave the same result as for the S4 and S16 of $1800 \mathrm{~kg} / \mathrm{m}^{3}$ above. Amongst the specimens, toner inclusion on sand or brick made specimens, namely, S16, S19, S20 and S18, produced very finely (0.01 to 3.0) $\mu \mathrm{m}$ well-spread net of independent pore matrix, which exhibited high compressive strength of $(48.1,43.8,33.4$, and 15.0$) \mathrm{N} / \mathrm{mm}^{2}$ respectively, with comparatively low porosity ratio of $(39.6,46.6,57.0$ and 57.7$) \%$.

Meanwhile, MK20 inclusion on sand or brick made specimens, namely S4, S14 and S15, produced almost similar net of pore matrix, having compressive strength of $(49.7,46$ and 25.6$) \mathrm{N} / \mathrm{mm}^{2}$ respectively, with comparatively low porosity ratios of $(39.8,44.5$ and 51.6)\% mentioned above. It is worth noting that S15, which exhibited slightly higher compressive strength of $25.6 \mathrm{~N} / \mathrm{mm}^{2}$, is of the $1100 \mathrm{~kg} / \mathrm{m}^{3}$ density. Regardless of density and porosity ratio measure, FC mix made with sand or brick only, exhibited an irregular and unevenly spaced comparatively bigger pore matrix, namely, specimens S3, S11, S12, and S13. For these, the density and curing period are the two factors that contribute to the strength, the denser and the more aged specimens, and higher compressive strength of $S 11$ with $1800 \mathrm{~kg} / \mathrm{m}^{3}$ and $47.3 \mathrm{~N} / \mathrm{mm}^{2}$, followed by S12, S13, and S3 with $\left(40.6,14.1\right.$ and 7.4) N/mm ${ }^{2}$ respectively. Specimens with MK30 and MK50 inclusion, namely, S7, S8, and S10 exhibited comparatively high porosity of $(65.1,70$ and 77.7) $\%$ respectively, while maintaining slight improvement on compressive strength of $(38,31$ and 26.1) $\mathrm{N} / \mathrm{mm}^{2}$ in comparison to $\mathrm{S} 3$ of sand only made specimen, having $7.4 \mathrm{~N} / \mathrm{mm}^{2}$ compressive strength. 


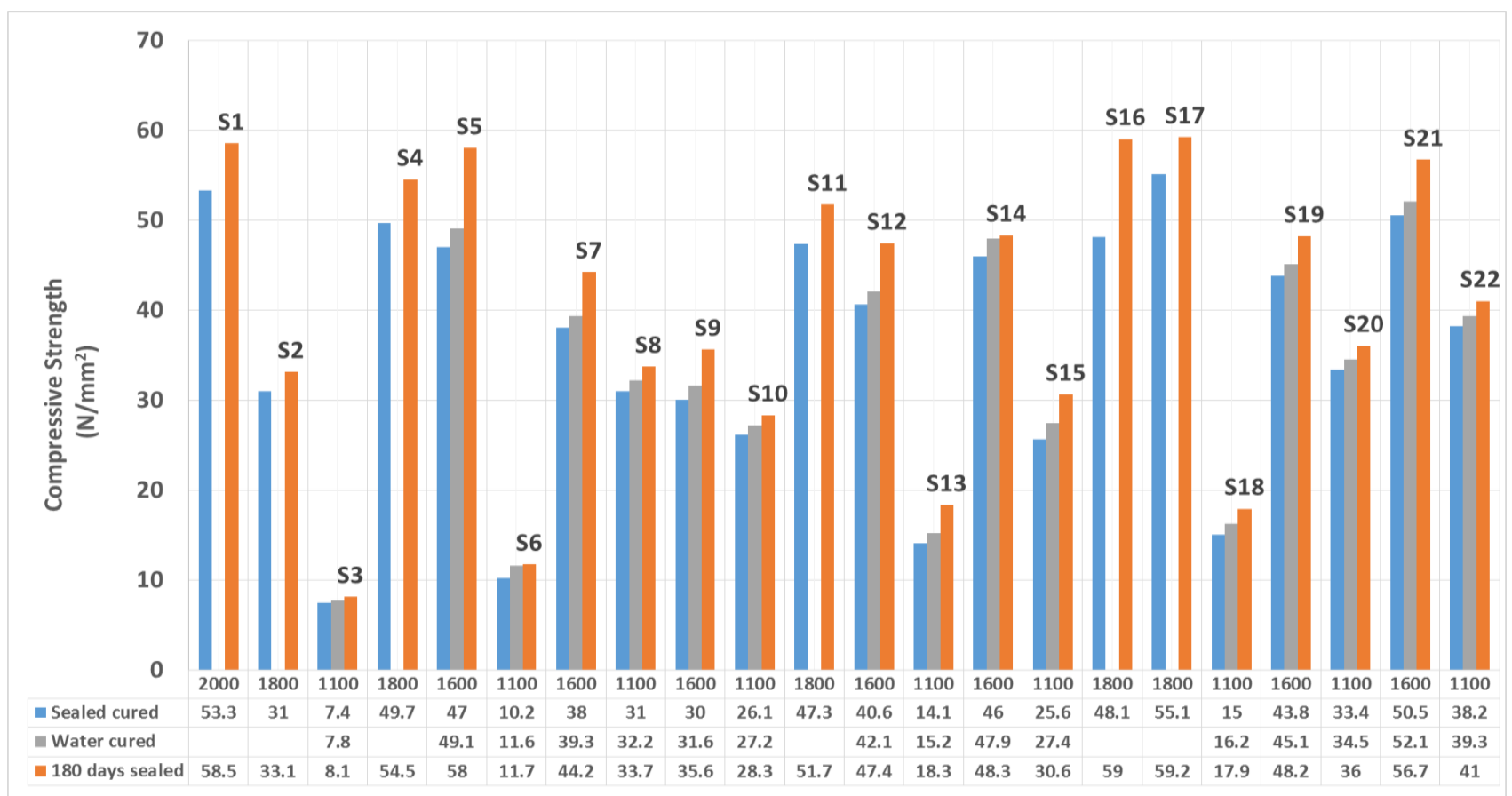

Density $\left(\mathrm{Kg} / \mathrm{m}^{3}\right)$

Figure 4 Compressive strength versus density for different mixes contain sand and brick as fillers, with the inclusion of toner and MK as additives, for specimens with either (28 and 180) days air sealed curing, or 28 days selective water curing.

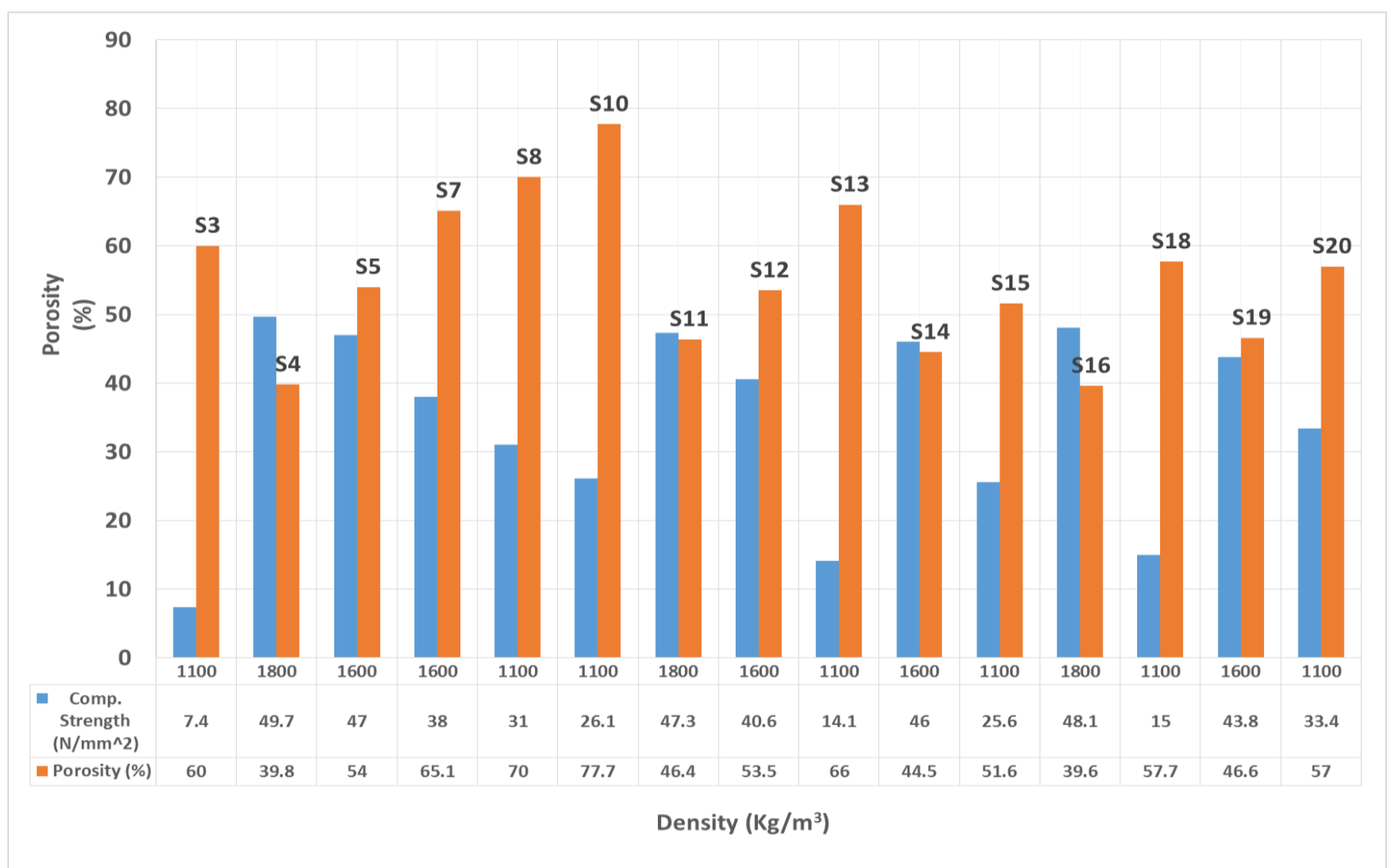

Figure 5 Porosity versus density and compressive strength for different mixes contain sand and brick as fillers, with the toner and $\mathrm{MK}$ as additives for selective air sealed cured specimens at 28 days. 
Back Scatered images

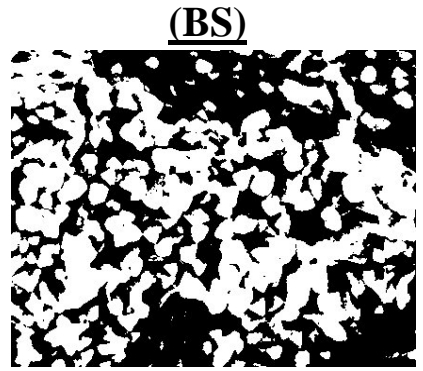

S3

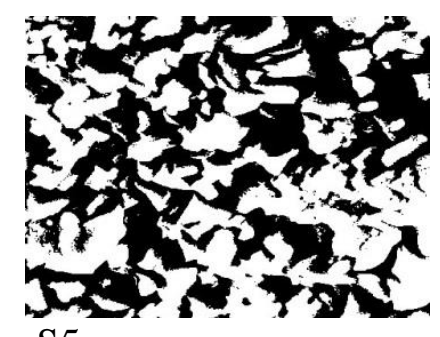

S5

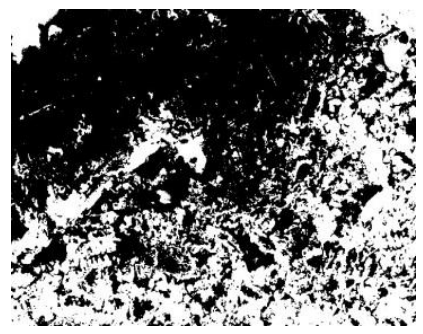
S8

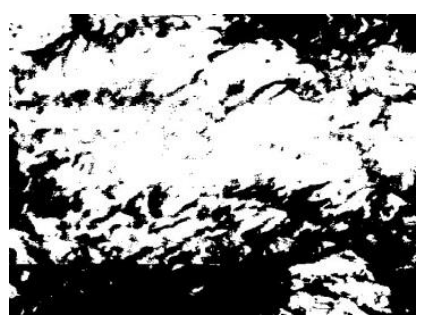
S11

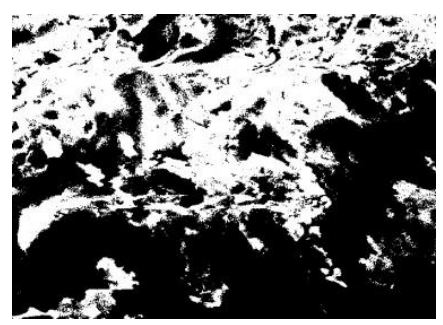
S13

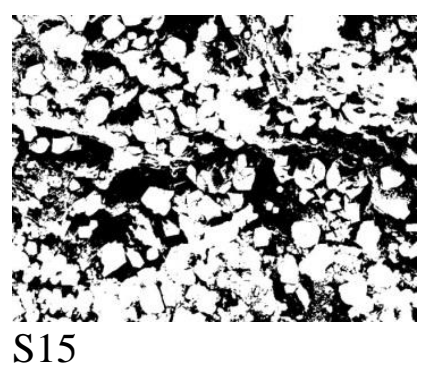

$\underline{\text { SEM images at 2000X }}$
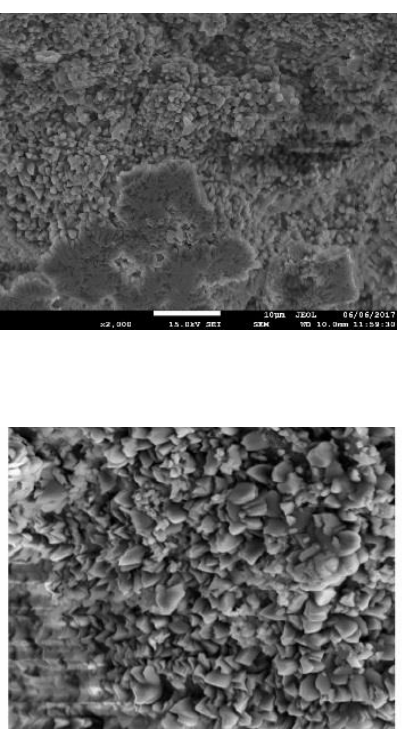

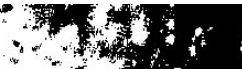

$+y^{5}+42+4$ $-4+2+4$

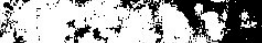

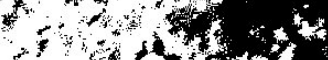

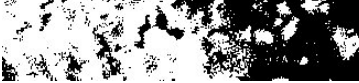

S7
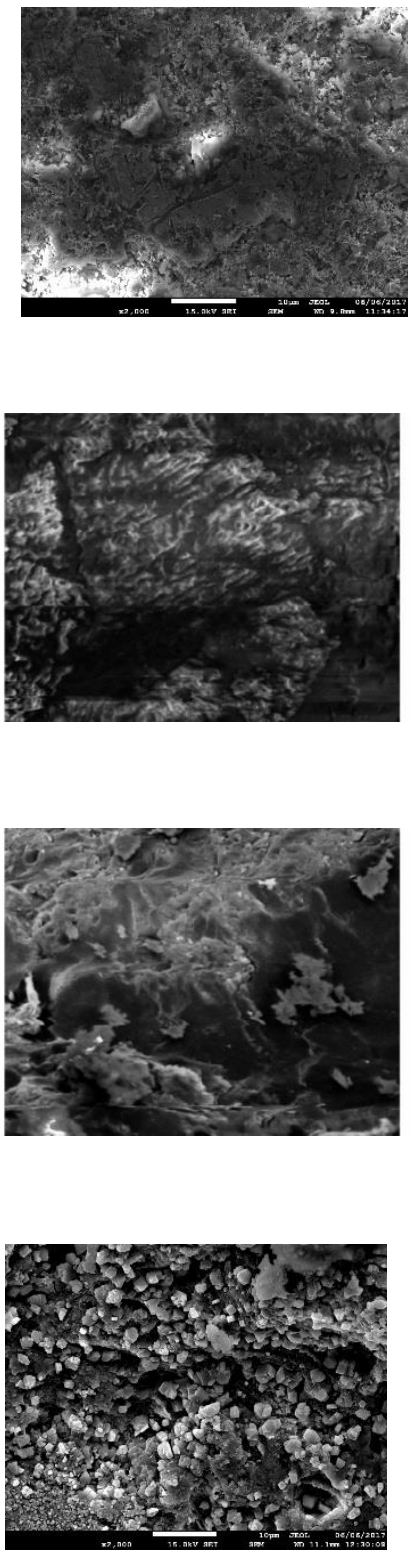

\section{S10}

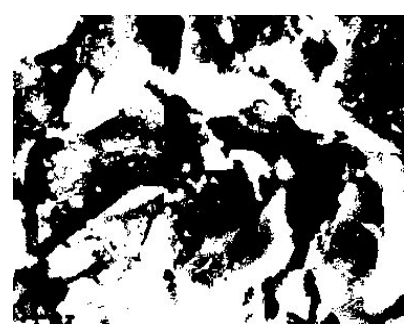

S12

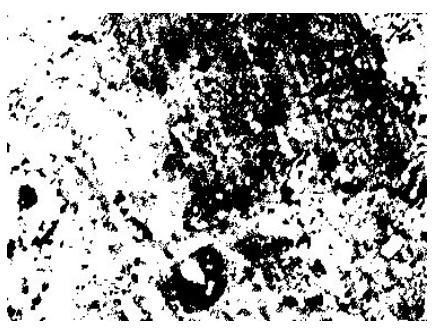

S14

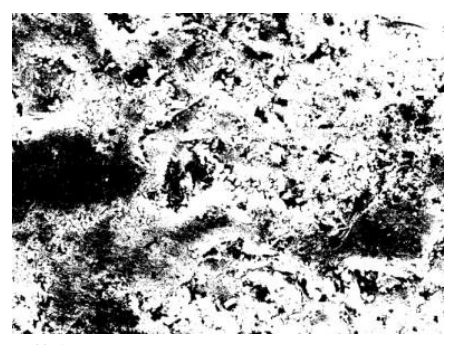

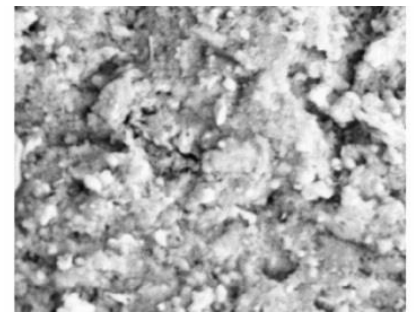
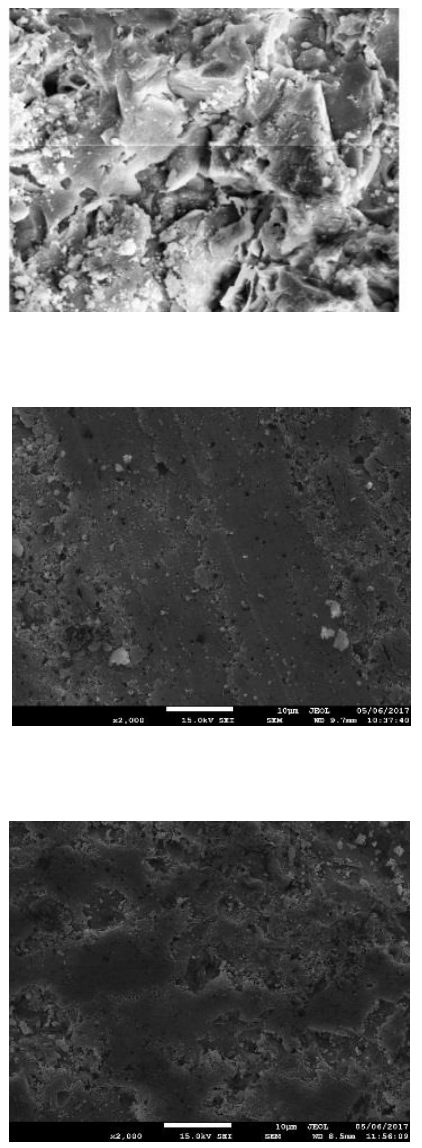

S16
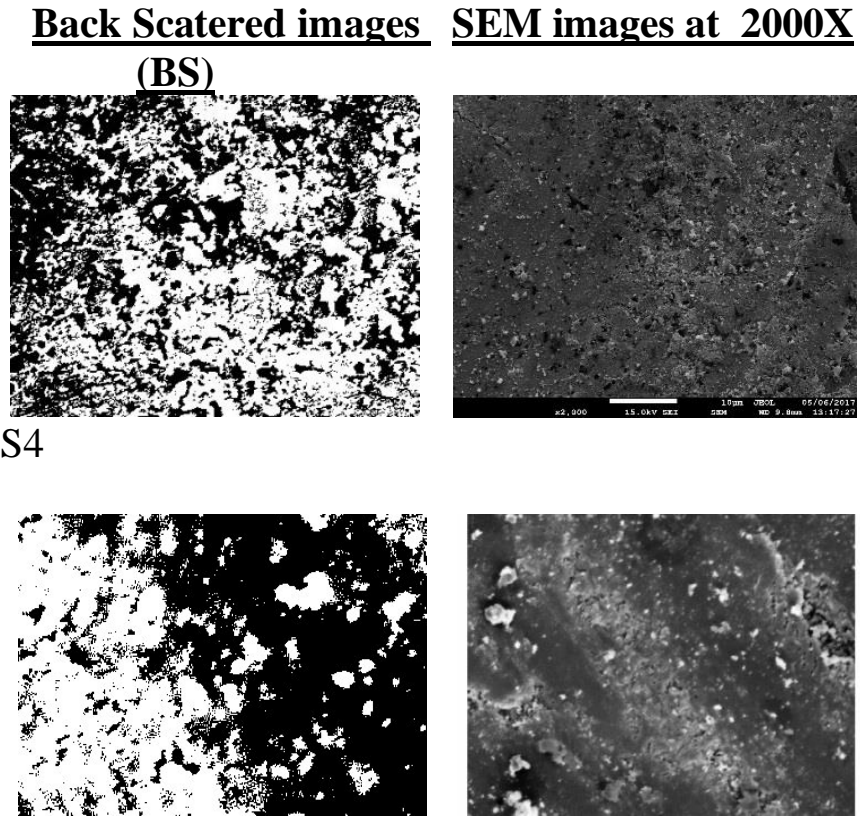

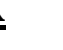




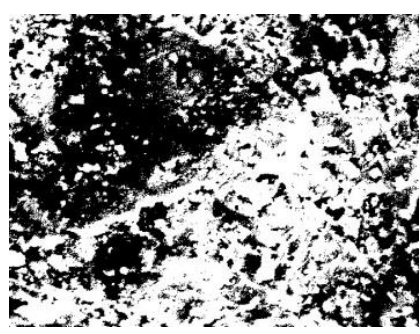

S18

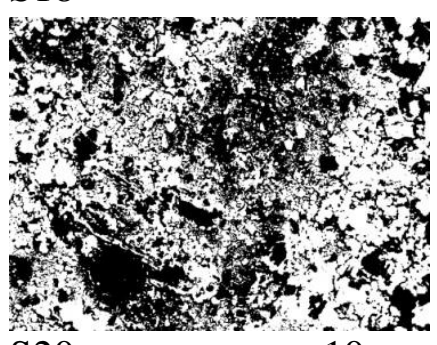

S20

$10 \mu \mathrm{m}$
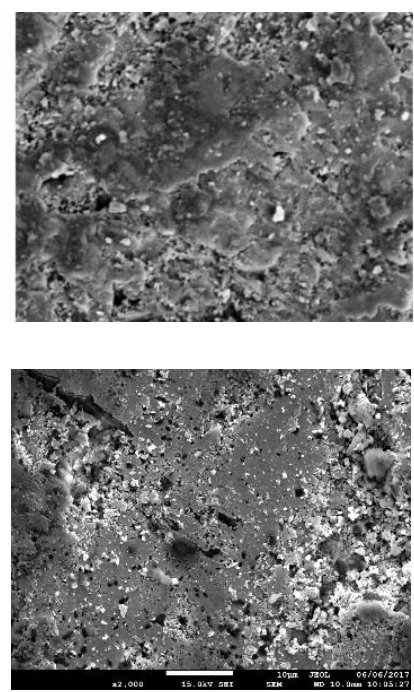

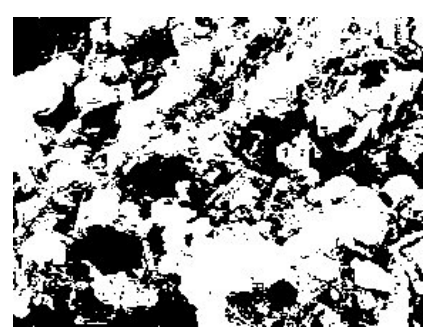

$10 \mu \mathrm{m}$

S19

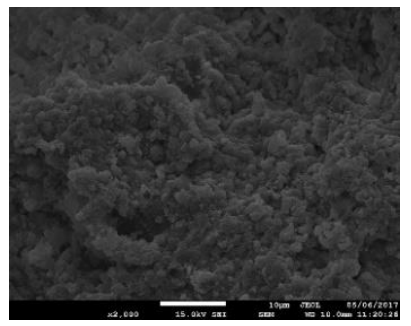

Figure 6 Back scattered (BS) and SEM images of the selective fifteen (S3 to S20) FC specimens investigated.

\subsection{CONCLUSION}

The following conclusions have been drawn from the present study:

- It is possible to produce FC with high compressive strength in the range of (28.5 to 59.2$) \mathrm{N} / \mathrm{mm}^{2}$ which can be used for structural elements with a variety of materials using different techniques.

- The best FC can be produced at $1600 \mathrm{~kg} / \mathrm{m}^{3}$ density to include all the beneficial properties required for structural purposes, such as, low porosity, low permeability and high compressive strength.

- With the results of this study, it is possible to get an FC with the required compressive strength for structural use at $1100 \mathrm{~kg} / \mathrm{m}^{3}$ density, but with lower grade properties.

- For mixes made without the inclusion of toner and MK, the well-known statement is true, compressive strength is directly related to concrete density; concrete of high density exhibits low porosity and high compressive strength, and vice versa, but this is untrue for those mixes made with the inclusion of toner and MK. Therefore, density and porosity are not always the decisive factors over strength, it is possible to produce a light weight and relatively porous FC of $1100 \mathrm{~kg} / \mathrm{m}^{3}$ density, but with the required high strength up to $38.2 \mathrm{~N} / \mathrm{mm}^{2}$ using toner and MK20 as additives for this purpose.

- For a given density, compressive strength of FC depends on materials used (filler and additive types), porosity of which are the shape factor, pore size, and pore size distribution of the matrix, as well as maturity of the FC beyond 28 days of curing.

- Regardless of density and porosity, FC microstructure through SEM images investigation revealed that the FC mix made with sand or brick only exhibits irregular and unevenly spaced relatively bigger micro pores of the size in the range of (10 to 70) $\mu \mathrm{m}$, while those made with the inclusion of toner, have a matrix of finer micro pores of the sizes in the range of (0.01 to 3.0) $\mu \mathrm{m}$ and (0.01 to 10.0) $\mu \mathrm{m}$ for those made with MK20 inclusion, all of which are evenly distributed.

- FC has the ability to gain more strength at different percentage ratios for all the specimens, but picking up the minimum 5\% for S14, and maximum $29.8 \%$ for S13 as examples with maturity up to 180 days period of sealed curing method.

- Contrary to the conventional method of air sealed curing, water curing method can equally give the same result in respect of compressive strength and slightly better for some particular densities.

- MK50 and MK30 inclusion, produces a highly porous matrix, but still can improve the compressive strength of the FC slightly to exceed those of the same densities, made without this inclusion. 


\section{REFERENCES}

[1] Nambiar E.K.K and Ramamurthy K., 2007b. Sorption characteristics of foam concrete, Cement and Concrete Research 37, pp. 1341-1347.

[2] Mydin, M.A.O. and Wang, Y.C. (2011). 'Structural performance of lightweight steel-foamed concrete-steel composite walling system under compression', Thin-Walled Structures, 49(1), pp. 66-76.

[3] British Cement Association, Ref. 46.042, 1994, pp 4. Foamed concrete; Composition and Properties.

[4] Dransfield J.M., 2000. Foamed Concrete: Introduction to the Product and its Properties, one-day awareness seminar on 'Foamed Concrete: Properties, Applications and Potential, University of Dundee, Scotland, pp.1-11.

[5] Jones, M.R. and McCarthy, A., 2005b. Preliminary views on the potential of foamed concrete as a structural material. Magazine of Concrete Research 57(1), pp. 21-31.

[6] Jones M.R., 2000. Foamed concrete for structural use, one-day awareness seminar on 'Foamed Concrete: Properties, Applications and Potential', University of Dundee, Scotland pp. 54-79.

[7] Ramamurthy K., Nambiar E.K.K., and Ranjani G.I.S., 2009. A classification of studies on properties of foam concrete. Cement and Concrete Composites 31, 388-396.

[8] Visagie M. and Kearsely E.P., 2002. Properties of foamed concrete as influenced by air-void parameters. Concrete Beton 101, 8-14.

[9] Luping T., 1986. A study of the quantitative relationship between strength and pore-size distribution of porous materials. Cement and Concrete Research 16, 87-96.

[10] Durack J.M and Weiqing L., 1998. The properties of foamed air cured fly ash based concrete for masonry production. In: Page A, Dhanasekar M, Lawrence S, editors. Proceedings of 5th Australasian Masonry Conference, Gladstone,Queensland, Australia, pp. 129-38.

[11] Ambroise J., Murat M. and Pera J., 1985. Hydration reaction and hardening of calcined clays and related minerals. Cement and Concrete Research 15: 261-268.

[12] Khatib J.M. and Wild S., 1996. Pore size distribution of metakaolin paste. Cement and Concrete Research 26(10), pp. 1545-1553.

[13] Gleize P.J.P., Cyr M. and Escadeillas G., 2007. Effects of metakaolin on autogenous shrinkage of cement pastes. Cement and Concrete Comp 29: 80-87.

[14] Khatib J.M. and Clay R.M. 2004. Absorption characteristics of metakaolin concrete. Cement and Concrete Research 34(1):19-29.

[15] Bai J., Wild S. and Gailius A., 2004. Accelerating Early Strength Development of Concrete, using Metakaolin as an Admixture. Materials Science (medziagotyra). Vol. 10, no. 4.

[16] Debieb F. and Kenai S. b., 2008. The use of coarse and fine crushed bricks as aggregate in concrete. Construction and Building Materials 22, 886-893.

[17] Khatib J.M., 2005. Properties of concrete incorporating fine recycled aggregate. Cement and Concrete Research 35:763-9.

[18] Poon C.S and Chan D., 2007. The use of recycled aggregate in concrete in Hong Kong. Resources, Conservation Recycling, 50(3): 293-305.

[19] Cachim P.B., 2009. Mechanical properties of brick aggregate concrete. Construction and Building Materials 23, 1292-1297.

[20] Ibrahim N.M., Salehuddin S., Amat R.C., Rahim N.L and Izhar T.N.T., 2013. Performance of Lightweight Foamed Concrete with Waste Clay Brick as Coarse Aggregate. APCBEE, Procedia 5, $497-501$.

[21] Aliabdo A.A., Abd-Elmoaty A.M., and Hassan H.H., 2014. Utilization of crushed clay brick in cellular concrete production. Alexandria Engineering Journal, 53, 119-130.

[22] Sandra V.P, 2014. Harvard Physico-chemical and toxicological studies of engineered nanoparticles emitted from printing equipment. Harvard school of public health.

[23] Jones, M.R. and McCarthy, A., 2006. Heat of hydration in foamed concrete: Effect of mix constituents and Plastic density. Cement and Concrete Research 36(6), pp. 1032-1041.

[24] Nicholas B Winter, 2012. Scanning Electron Microscopy of the Cement and Concrete.

[25] BS EN 12390-3:2009, Testing hardened concrete. 